\title{
Changes in Mediterranean rocky-reef fish assemblages exposed to sewage pollution
}

\author{
P. Guidetti*, A. Terlizzi, S. Fraschetti, F. Boero \\ Laboratory of Zoology and Marine Biology, DiSTeBA, CoNISMa, University of Lecce, Via Provinciale Monteroni, \\ 73100 Lecce, Italy
}

\begin{abstract}
The fish fauna associated with shallow subtidal rocky-reefs in southern Apulia (SE Italy, Mediterranean Sea) was investigated to assess whether fish assemblage structure, and temporal trends in species richness and abundance of fishes were affected by sewage pollution. Fish assemblages were evaluated by visual census at 3 locations ( 3 to $4 \mathrm{~km}$ apart), 1 putatively impacted by a sewage outfall (discharge rate from 200 to $600 \mathrm{~m}^{3} \mathrm{~h}^{-1}$ ) and 2 controls; within each location, 3 sites (100 to $300 \mathrm{~m}$ apart) were surveyed 4 times over the study year. In general, dissimilarities in assemblage structures between the 2 controls were always lower than between each control and the outfall location. During winter, however, the dissimilarities between controls were very low and similar to those between each control and the outfall location, suggesting that in this period, fish assemblages from the outfall did not greatly differ from those in the controls. Planktivorous and detritivorous fishes were more abundant at the impacted location and contributed most to dissimilarities in assemblage structures between the outfall and controls. Furthermore, the outfall significantly affected total fish abundance (which was consistently about 5-fold greater at the outfall than at the controls), and temporal trends in the average density of sparids and small serranids at the scale of locations, while small benthic fishes were influenced at the scale of sites (within locations). Particulate feeders and planktivorous fishes showed different temporal trends in average densities between outfall and controls at both spatial scales examined. Species richness and density of herbivorous fishes did not show significant differences attributable to the outfall. The data thus show that nearshore sewage discharges have the potential to alter spatio-temporal patterns in littoral fish assemblages.
\end{abstract}

KEY WORDS: Sewage impact · Fish assemblages · Species richness · Asymmetrical sampling design · Mediterranean Sea

Resale or republication not permitted without written consent of the publisher

\section{INTRODUCTION}

The Mediterranean basin is one of the many areas in the world that have experienced, in recent decades, dramatic coastal development because of increasing human populations and industrial usage. This development has adversely affected the marine environment and its biota through nutrient enrichment, thermal and chemical pollution, sedimentation, etc. (UNEP 1989). This problem has awoken global interest in maximising management strategies of point-source impacts (such as sewage outfalls), which apparently affect littoral systems locally, but whose effects may often have an im- pact over far greater spatial scales (Gray 1996, Raimondi \& Reed 1996, Costanzo et al. 2001).

Marine biological assemblages typically change naturally across various spatial and temporal scales through seasonal changes in environmental conditions (e.g. coastal hydrodynamics, temperature, salinity) and biological processes (e.g. recruitment, predation, competition) (Dayton 1984, Danielson 1991). Human disturbances have the potential to alter natural patterns. Therefore an unambiguous assessment of the effects of point-source impacts on marine communities remains the first step in planning management strategies aimed at mitigating their effects on natural marine systems. 
Environmental impact assessments basically consist of measuring differences in the natural patterns and anthropogenic impacts. This impact assessment is a goal which may be achieved by the use of specific experimental designs and the careful choice of the most suitable biological assemblages, populations and/ or related variables for examination (Underwood 1994, Schmitt \& Osenberg 1996). In this respect, asymmetrical sampling designs (Underwood 1991, 1992, 1993, Glasby 1997) have been demonstrated by many studies to be powerful tools in evaluating the effects of point-source impacts. Whenever possible, an experimental design for environmental assessments should include 'before' and 'after' data (i.e. before and after impact occurs). 'Before-after control-impact' (BACI) designs are an ideal tool for impact studies (Underwood 1994, Schmitt \& Osenberg 1996). When there are no data on marine systems before impact, 'after' studies may nevertheless make it possible to analyse some aspects of the disturbance, although considerable care is needed in the interpretation of such results (Underwood 2000). The choice of the biotic component to be investigated is strictly dependent on the aim of the research (Warwick 1993, Warwick \& Clarke 1993), the habitat under investigation, and the scale on which the putative impact is expected to affect the system.

Among the various kinds of anthropogenic impacts potentially affecting coastal marine assemblages, sewage outfalls have received considerable attention in the recent literature. Most of the available studies on sewage effects on marine environments concern softbottom benthic assemblages (Pearson \& Rosenberg 1978, Austen et al. 1989, Diener et al. 1995, Estacio et al. 1997). However, in recent years increasing attention has been paid to sessile macrobenthos living on hard substrata (Smith 1996, Underwood \& Chapman 1996, Roberts et al. 1998, Archambault et al. 2001, Soltan et al. 2001, Terlizzi et al. 2002). A few papers have dealt with the responses of plankton to sewage (see Warwick 1993 for review), and several authors have studied the effects of outfalls on adult fishes (Smith et al. 1999) and their larvae (Gray 1996, Kingsford \& Gray 1996). These studies covered the impact of outfall effluents on diversity, abundance, patterns of aggregation, assemblage structures, mortality, fecundity, and susceptibility to infections (Guidetti et al. 2002 and references therein). The advantages of using adult fish assemblages for environmental assessment studies are 2-fold: (1) there are fewer problems with taxonomic fish identification than with benthic fauna identification (Warwick 1993, Hall et al. 1997); (2) visual underwater methods, which are fast and effective standardised procedures for collecting quantitative data in situ, may be used (see Harmelin-Vivien et al. 1985). Furthermore, the reaction time of a faunal component to perturbation may be important in assessing changes in the structure of an animal assemblage. Because of their mobility, fishes display a rapid avoidance or attractant response to a contaminated area in a period of a few days or hours, a time frame that is intermediate to the instantly available results of chemical assays and the delayed response of benthic communities, which usually respond more slowly to changes in environmental quality (Pomfret et al. 1991).

In SW Apulia (SE Italy), the marine protected area (MPA) of Porto Cesareo was formally established in 1997, but to date has been protected in name only. The sewage outfall of the city of Nardò, which discharges onshore near the coastline inside the MPA boundaries, is antithetical to tourism and environmental conservation. Recent preliminary studies have demonstrated that this outfall is able to affect the spatial distribution of fishes (Guidetti et al. 2002) and sessile macrobenthic assemblages (Terlizzi et al. 2002) associated with rocky substrates.

The purpose of this study was to assess whether point-source sewage pollution has the potential to influence spatio-temporal variability in the distribution patterns of fish assemblages associated with shallow subtidal rocky reefs along the SW coast of Apulia.

\section{MATERIALS AND METHODS}

Study area. Surveys were carried out at 3 locations on the SW Apulian coast (Ionian Sea, SE Italy: Fig. 1). The area is characterised by a calcarenitic rocky plateau with a gentle to medium slope which declines from the water surface to about 8 to $12 \mathrm{~m}$ depth over sand. The location putatively impacted by sewage (Location I) is characterised by a rocky substrate covered by a well-diversified algae assemblage (see Terlizzi et al. 2002). The outfall, which directly discharges treated waste waters onshore near the coastline, usually serves nearly 30000 inhabitants. Waste-water is discharged at flow rates varying from 200 to $600 \mathrm{~m}^{3}$ $\mathrm{h}^{-1}$, and is biologically treated (aerobic and anaerobic digestion) and chemically disinfected before discharging. During the tourist seasons (chiefly summer), the actual population served by this plant is however far greater, and technical problems often prevent complete water treatment. Two control locations (Locations C1 and C2) with similar environmental features (depth, substrate, slope, etc.) were selected randomly about 3 to $4 \mathrm{~km}$ north (C1) and south (C2) of Location I. Overall, the total cover of sessile benthos does not differ markedly between the 3 locations, but red algae of the genera Pterocladiella and Gelidium and the brown alga Colpomenia sinuosa are more abundant or exclusively present at Location I (Terlizzi et al. 2002). 




Fig. 1. Sampling locations in SE Italy. I = impact location (i.e. impacted by sewage outfall); C1, C2: control locations. MPA: marine protected area

Data collection and experimental design. Underwater visual censuses were performed along transects $25 \mathrm{~m}$ long and $5 \mathrm{~m}$ wide (see Harmelin-Vivien et al. 1985 for review). The 'transect' technique was selected among the available visual methods as the most appropriate for both smaller specimens and fast-swimming species (Harmelin-Vivien \& Francour 1992). Fish abundance was estimated by counting single specimens to a maximum of 10 individuals, and using abundance classes (11-30, 31-50, 51-100, 101-200, 201-500, $>500$ individuals) for schools. This recording system leads to similar degrees of error over a wide range of abundances, ensuring homogeneity of variance after log-transformation of the data (Frontier 1986).

At each of the 3 locations (I, C1, C2), 3 sites were selected randomly about 100 to $300 \mathrm{~m}$ apart. At each of the 3 sites within each location, 3 replicate censuses were performed on 4 dates chosen at random (Time $1=$ May 2000; Time 2 = July 2000; Time 3 = February 2001; Time 4 = July 2001) over a total of 108 fish transects.

Ecological fish categories. Groups of fishes with similar ecological requirements were aggregated into 7 ecological categories (in some cases corresponding to families), defined on the basis of their feeding habits and spatial organisation in the water column (acro- nyms follow Guidetti et al. 2002): (1) POM: particulate organic matter feeders (i.e. Mugilidae); (2) PLA: planktivorous fishes inhabiting the water column, often aggregated in schools (e.g. Atherinidae, Centracanthidae, Pomacentridae and the sparid Oblada melanura); (3) LAB: mesocarnivorous nectobenthic fishes belonging to Labridae; (4) SPA: meso- and macrocarnivorous sparids of the genus Diplodus, Lythognathus mormyrus and Spondyliosoma cantharus; (5) SER: small serranids (Serranus spp.), site-attached piscivorous fishes primarily feeding on juvenile stages; (6) HERB: herbivorous fishes (the sparid Sarpa salpa and the scarid Sparisoma cretense); (7) BEN: benthic mesocarnivorous fishes (e.g. Blennidae, Gobidae, Tripterygidae).

Occasional species that could not be attributed to the above ecological categories, such as the moronid Dicentrarchus labrax, the carangid Seriola dumerili, Sphyraenidae, and Apogon imberbis were excluded from the analyses.

Multivariate statistical analyses. Multivariate techniques were used to analyse fish assemblage structures (species composition and relative abundances) using the PRIMER software package (Plymouth Marine Laboratory, UK; Clarke \& Warwick 1994). Data of the fish abundances in the different ecological categories (see the previous subsection) were logtransformed to reduce the weighting of abundant categories and increase that of rarer categories. The Bray-Curtis similarity matrix was used to generate 2-dimensional ordination plots with the non-metric multidimensional scaling (nMDS) technique (Clarke 1993). A 2-way nested analysis of similarity (ANOSIM) was first used to examine differences among sites and among locations at each of the 4 sampling times. Once it was observed that sites within locations were not always significantly different (see 'Results'), the data for all locations (i.e. without considering scale of site) were combined to enable a 1-way ANOSIM for each sampling time and comparison of pairs of outfall and control locations. The similarity percentages (SIMPER) procedure was used to identify the major categories of fishes contributing to dissimilarities.

Univariate statistical analyses. Since there was only a single outfall location, asymmetrical analyses of variance were employed to test for differences between the outfall and the 2 controls (Underwood 1992, 1993). It is worth noting that this is an 'after' study, since there are no data in the period 'before' the sewage outfall was constructed. Asymmetrical designs (beyond BACI), their mechanics and potential for detecting both temporal and spatial disturbances have been widely discussed by Underwood (1991, 1992, 1993, 1994) and Glasby (1997). In the present study, the outfall was in operation on all 4 random sampling occa- 
sions. The 'impact vs controls' (I vs Cs) term was considered fixed and orthogonal to time, while the term 'between controls' was random. Sites were randomly nested within locations. First, the data (i.e. number of species and fish abundance, including both total fish abundance and density of each ecological category) from both the outfall and controls were analysed using a fully orthogonal design in which sites were nested within locations. A second analysis was then done on only those data associated with the controls. The asymmetrical components were thus calculated by subtracting the sums of squares of the second analysis from those of the first. What was left was the variance associated with the putatively impacted outfall location. The various factors involved in the analyses were calculated with the same logic. Significant higher-order interactions (e.g. Time $\times$ Sites[Cs]) mean that lowerorder interactions and main effects usually cannot be interpreted and should not be reported (Underwood 1997). Nevertheless, where higher-order interactions were found to be significant, the $\mathrm{T} \times \mathrm{I}$ vs Cs interaction was reported in order to examine the trend above these higher-order interactions (see Roberts et al. 1998 for further details). Where significant Time $x$ Sites(Location) interactions occurred, a 2-tailed F-test was used to compare the temporal variability among sites from the outfall location with the variability among sites within control locations (Underwood 1992), allowing a direct comparison of the effects of the outfall over this smaller spatial scale.

Prior to analysis, homogeneity of variance was tested by Cochran's test and, whenever necessary, abundance data were transformed to $\ln (x+1)$. If transformations did not produce homogeneous variances, ANOVA was, nevertheless, used after setting $\alpha$ to 0.01 in order to compensate for the increased likelihood of Type I error (Underwood 1997). ANOVAs were performed using the GMAV5 software package (University of Sydney).

\section{RESULTS}

We identified 38 fish taxa. Table 1 lists the taxa recorded at the outfall (Location I $=31$ taxa) and controls (Locations C1 and C2: 32 and 33, respectively). Atherinids, mugilids and sphyraenids could not be identified to species level by direct visual observations.

\section{Whole fish assemblages}

The nMDS plots of fish assemblage structures at the 4 sampling times (Fig. 2) show a clear-cut separation (Fig. 2a,b,c) between individual fish counts at Loca-
Table 1. List of fish taxa (+: present; -: absent) recorded at each of the 3 locations investigated. Location I: impacted by sewage; Locations C1 and C2: controls. EC: ecological category. POM: particulate organic matter feeders; PLA: planktivorous fishes; LAB: labrids; SPA sparids; SER: small serranids; HERB: herbivores; BEN: benthic mesocarnivores; full details in 'Materials and methods'

\begin{tabular}{|c|c|c|c|c|}
\hline \multirow{2}{*}{$\begin{array}{l}\text { Family } \\
\text { species }\end{array}$} & \multirow[t]{2}{*}{$\mathrm{EC}$} & \multicolumn{3}{|c|}{ Location } \\
\hline & & I & $\mathrm{C} 1$ & $\mathrm{C} 2$ \\
\hline \multicolumn{5}{|l|}{ Apogonidae } \\
\hline Apogon imberbis & $\mathrm{BEN}$ & + & + & + \\
\hline Atherinidae (unidentified) & PLA & + & + & + \\
\hline \multicolumn{5}{|l|}{ Blenniidae } \\
\hline Parablennius gattorugine & BEN & + & + & + \\
\hline P. rouxi & $\mathrm{BEN}$ & + & + & + \\
\hline \multicolumn{5}{|l|}{ Carangidae } \\
\hline Seriola dumerili & & - & + & - \\
\hline \multicolumn{5}{|l|}{ Centracanthidae } \\
\hline Spicara maena & PLA & + & + & - \\
\hline \multicolumn{5}{|l|}{ Gobiidae } \\
\hline Gobius bucchichii & $\mathrm{BEN}$ & + & + & + \\
\hline G. geniporus & $\mathrm{BEN}$ & + & - & + \\
\hline \multicolumn{5}{|l|}{ Labridae } \\
\hline Coris julis & LAB & + & + & + \\
\hline Labrus merula & LAB & + & - & + \\
\hline L. viridis & LAB & + & + & - \\
\hline Symphodus cinereus & LAB & + & + & + \\
\hline S. doderleini & LAB & - & + & + \\
\hline S. mediterraneus & LAB & - & + & + \\
\hline S. ocellatus & LAB & + & + & + \\
\hline S. roissali & LAB & + & + & + \\
\hline S. rostratus & LAB & - & + & - \\
\hline S. tinca & LAB & + & + & + \\
\hline Thalassoma pavo & LAB & + & + & + \\
\hline \multicolumn{5}{|l|}{ Moronidae } \\
\hline Dicentrarchus labrax & & - & - & + \\
\hline Mugilidae (unidentified) & POM & + & + & + \\
\hline \multicolumn{5}{|l|}{ Mullidae } \\
\hline Mullus surmuletus & $\mathrm{BEN}$ & + & + & + \\
\hline \multicolumn{5}{|l|}{ Pomacentridae } \\
\hline Chromis chromis & PLA & + & + & + \\
\hline \multicolumn{5}{|l|}{ Scaridae } \\
\hline Sparisoma cretensis & HERB & + & + & + \\
\hline \multicolumn{5}{|l|}{ Scorpaenidae } \\
\hline Scorpaena porcus & BEN & - & + & + \\
\hline \multicolumn{5}{|l|}{ Serranidae } \\
\hline Serranus cabrilla & SER & + & + & + \\
\hline S. scriba & SER & + & + & + \\
\hline \multicolumn{5}{|l|}{ Sparidae } \\
\hline Diplodus annularis & SPA & + & + & + \\
\hline D. puntazzo & SPA & + & + & + \\
\hline D. sargus & SPA & + & + & + \\
\hline D. vulgaris & SPA & + & + & + \\
\hline Lythognathus mormyrus & SPA & + & - & - \\
\hline Oblada melanura & PLA & + & + & + \\
\hline Sarpa salpa & HERB & + & + & + \\
\hline Spondyliosoma cantharus & SPA & - & + & + \\
\hline Sphyraenidae (unidentified) & & + & - & + \\
\hline \multicolumn{5}{|l|}{ Tripterygiidae } \\
\hline Tripterygion delaisi & BEN & + & + & + \\
\hline T. minor & BEN & + & - & + \\
\hline
\end{tabular}



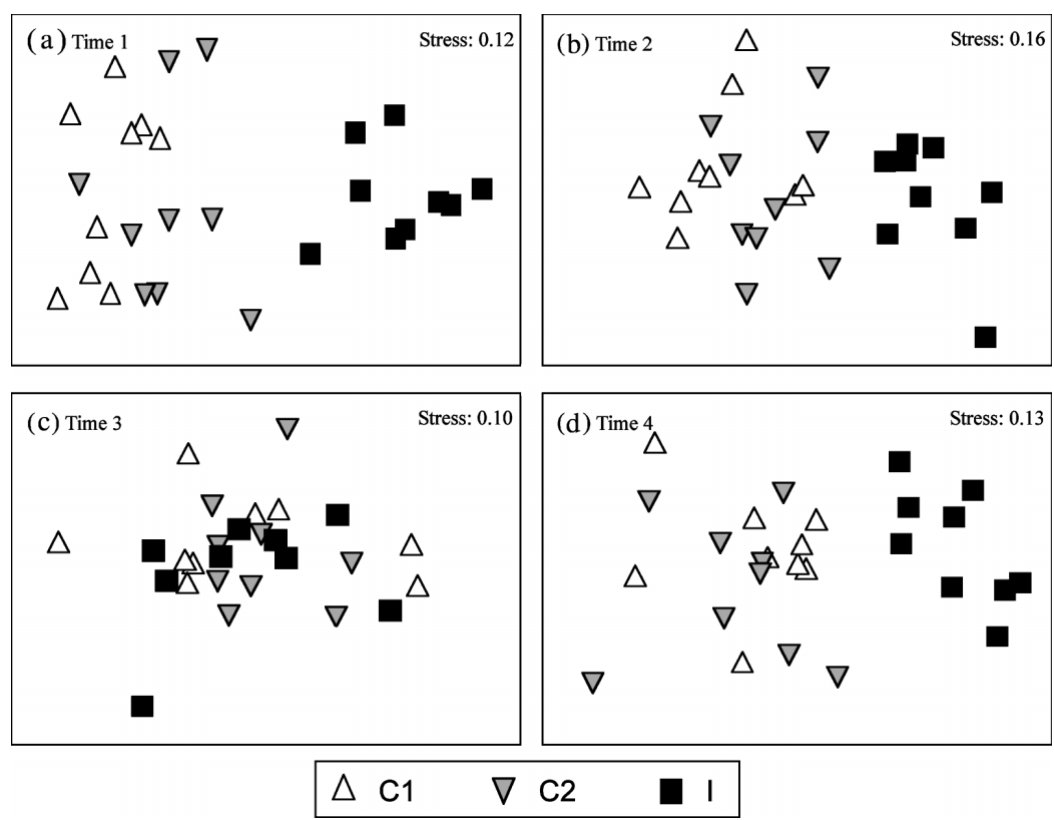

Fig. 2. Two-dimensional non-metric multidimensional scaling ordinations of individual replicates comparing fish assemblages from sewage-impacted (Location I) and control (C1 and C2) locations. T1, T2: May, July 2000; T3, T4: February, July 2001, respectively

tions I vs $\mathrm{C} 1$ and $\mathrm{C} 2$ (fish counts at the 2 controls were mixed) throughout the study period, exept for Time 3 (Fig. 2c). A 2-way nested ANOSIM showed that differences in fish assemblage structures were significant among locations but not among sites at all sampling times exept T3 (i.e. February 2001).

For T3, no differences were detected among locations (and implicitly between Locations I and Cs) so that sites contributed to most of the dissimilarity among samples in this case only (Table 2). A 1-way ANOSIM was then performed to test for differences at the scale of locations at each of the 4 sampling times. Despite the significant variability in some cases between the 2 controls (e.g. at T2), the dissimilarities between $\mathrm{C} 1$ and $\mathrm{C} 2$ were always lower than those between either control location and Location I (Table 3). At T3, however, although significant, the dissimilarity between the controls was low and similar to that between each control location and Location I. SIMPER identified some fish categories as major contributors to the dissimilarities between Location I and Locations C1 and $\mathrm{C} 2$ at each sampling time (Table 4 ). Great densities of PLA characterised
Table 2. Two-way nested ANOSIM testing for differences in fish assemblage structures among sites and among locations at each of the 4 sampling times (T1, T2: May, July 2000; T3, T4: February, July 2001, respectively). ${ }^{*} \mathrm{p}<0.05$; ${ }^{* *} \mathrm{p}<0.01 ; \mathrm{ns}=$ not significant

\begin{tabular}{|lccrrrrrrr|}
\hline & T1 & & T2 & & T3 & T4 \\
& R-value & p & R-value & p & R-value & p & R-value & p \\
\hline Among sites & 0.151 & ns & 0.034 & ns & 0.427 & ${ }^{* *}$ & 0.150 & ns \\
Among locations & 0.728 & ${ }^{*}$ & 0.868 & ${ }^{* *}$ & 0.062 & ns & 0.506 & ${ }^{* *}$ \\
\hline
\end{tabular}

Table 3. One-way ANOSIM testing for differences in fish assemblage structures among locations (I: sewage impact; $\mathrm{C} 1$ and $\mathrm{C} 2$ : controls) at each of 4 sampling times. ${ }^{*} \mathrm{p}<0.05 ;{ }^{* *} \mathrm{p}<0.01 ; \mathrm{ns}=$ not significant

\begin{tabular}{|c|c|c|c|c|c|c|c|c|}
\hline & T1 & & T2 & & T3 & & $\mathrm{T} 4$ & \\
\hline & R-value & $\mathrm{p}$ & R-value & $\mathrm{p}$ & R-value & $\mathrm{p}$ & R-value & $\mathrm{p}$ \\
\hline Among locations & 0.623 & ** & 0.585 & ** & 0.157 & $*$ & 0.303 & ${ }^{* *}$ \\
\hline \multicolumn{9}{|l|}{ Pairwise tests } \\
\hline C1 vs C2 & 0.096 & ns & 0.427 & ** & 0.140 & * & 0.194 & * \\
\hline C1 vs I & 0.895 & ${ }^{* *}$ & 0.853 & ** & 0.186 & * & 0.319 & ** \\
\hline C2 vs I & 0.783 & ** & 0.524 & ** & 0.160 & * & 0.552 & ** \\
\hline
\end{tabular}


Table 4. SIMPER of ecological categories of fish (EC, abbreviations as in Table 1) contributing most (\%) to dissimilarity between Location I and control locations, and average density (AvD) during each of 4 sampling times. I: sewage-impacted location; Cs: controls (average for Locations C1 and C2)

\begin{tabular}{|c|c|c|c|c|c|c|c|c|c|c|c|c|c|c|c|}
\hline \multirow{3}{*}{$\overline{\mathrm{EC}}$} & \multirow{3}{*}{$\%$} & \multirow{2}{*}{\multicolumn{2}{|c|}{$\mathrm{T} 1 \mathrm{AvD}$}} & \multirow{3}{*}{$\overline{\mathrm{EC}}$} & \multirow{3}{*}{$\%$} & \multicolumn{2}{|c|}{$-\mathrm{T} 2$} & \multirow{3}{*}{$\overline{\mathrm{EC}}$} & \multirow{3}{*}{$\%$} & \multirow{2}{*}{\multicolumn{2}{|c|}{$\mathrm{AvD}$}} & \multirow{3}{*}{$\mathrm{EC}$} & \multirow{3}{*}{$\%$} & \multirow{2}{*}{\multicolumn{2}{|c|}{ AvD }} \\
\hline & & & & & & & AvD & & & & & & & & \\
\hline & & I & $\mathrm{Cs}$ & & & I & $\mathrm{Cs}$ & & & I & $\mathrm{Cs}$ & & & I & $\mathrm{Cs}$ \\
\hline PLA & 43.8 & 1131.23 & 119.2 & PLA & 28.6 & 1464.6 & 157.7 & POM & 34.0 & 182.2 & 0.1 & HERB & 23.9 & 26.6 & 15.1 \\
\hline SPA & 15.9 & 1.1 & 9.2 & HERB & 19.3 & 6.0 & 12.1 & SPA & 19.0 & 17.3 & 1.3 & PLA & 23.8 & 711.0 & 132.7 \\
\hline POM & 15.1 & 10.1 & 0.8 & SPA & 7.9 & 11.0 & 4.6 & PLA & 18.7 & 395.6 & 183.5 & POM & 16.2 & 13.6 & 0.1 \\
\hline SER & 11.1 & 0.3 & 3.2 & BEN & 7.3 & 3.1 & 1.9 & SER & 8.8 & 2.7 & 1.9 & SPA & 9.2 & 3.4 & 2.8 \\
\hline
\end{tabular}

variability between the control locations, an outfall impact on temporal trends of BEN was apparent at the site scale (Fig. 4g). In fact, 2-tailed F-tests revealed that temporal variability among sites at the outfall location was significantly different than that among control sites. ANOVAs, furthermore, revealed that temporal variability in average densities of POM and PLA (Fig. 4a,b) were highly affected by the outfall discharge at both spatial scales examined $(\mathrm{T} \times \mathrm{I}$ vs $\mathrm{Cs}$ interactions; 2-tailed F-tests significant). The average abundance of these 2 fish groups (PLA and POM) at
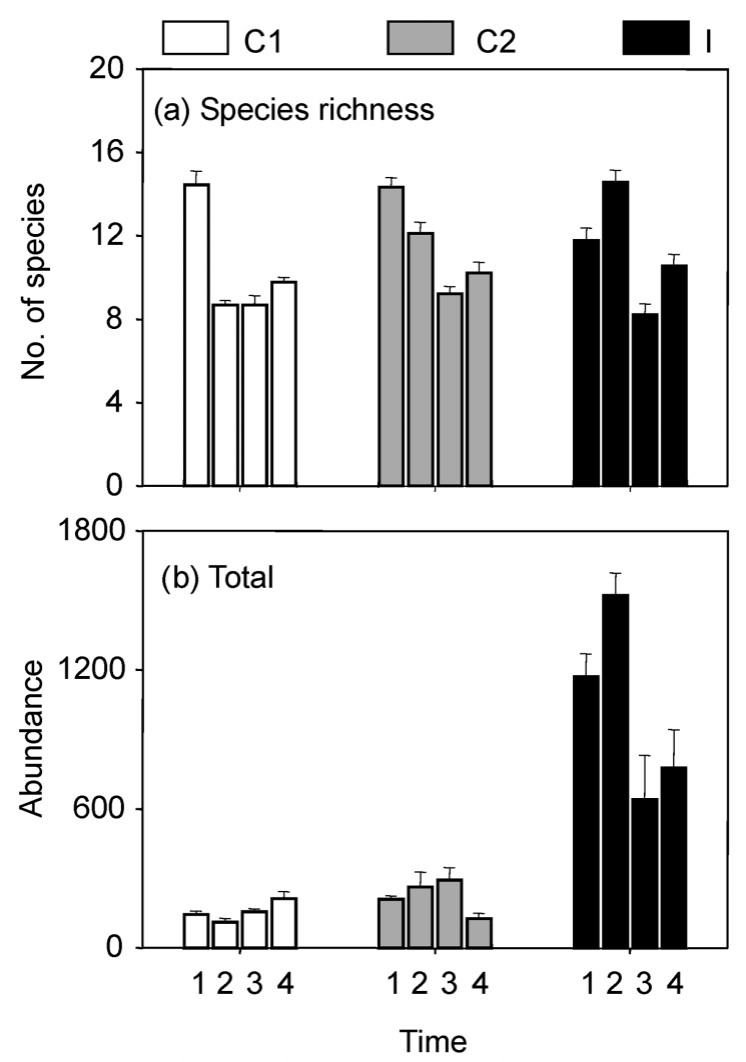

Fig. 3. Mean $( \pm \mathrm{SE})$ number of species and total fish abundance (number of individuals $125 \mathrm{~m}^{-2}$ ) at Location I (impacted by sewage outfall) and Locations C1 and C2 (controls) at each of 4 sampling times
Location I was greater than at C1 and C2 on all 4 sampling occasions. The average densities of LAB and HERB (Fig. 4c,f) appeared to be unaffected by the outfall.

\section{DISCUSSION AND CONCLUSIONS}

The present study provides evidence that pointsource sewage pollution affected spatio-temporal patterns of Mediterranean fish assemblages associated with shallow subtidal rocky substrates. Overall, such an anthropogenic impact appeared to influence assemblage structures, total fish abundance and density of several ecological categories of fishes.

Fish assemblage structures at the outfall clearly differed from the controls throughout the study year, but during winter these differences narrowed (MDS plots in Fig. 2). Although the lack of a nested temporal scale within each season prevents a formal assessment of seasonal patterns, the evidence suggests that in winter (the season with the fewest tourists and minimal sewage outflow) coastal fish assemblages may be less impacted than during other seasons. This could be related to the outfall efficiency (see 'Materials and methods') of the treatment plant studied. The outfall usually malfunctions during the summer, when increased population levels (tourist influx) overtax its maximum operating capacity. This hypothesis is, however, based merely on correlative evidence.

Samples of the sessile macrobenthos taken at the time of the fish survey showed that sessile assemblages at the outfall location differed from those at the controls at all sampling times (A. Terlizzi et al. unpubl. data). These results also showed that fish assemblages have a faster reaction time to sewage disposal than sessile benthos.

The fact that fish assemblage structures respond to various types of human disturbances has been widely demonstrated (Shepherd et al. 1992, Guidetti et al. 2002 and references therein). In the specific case of sewage pollution, however, there is a paucity of studies 


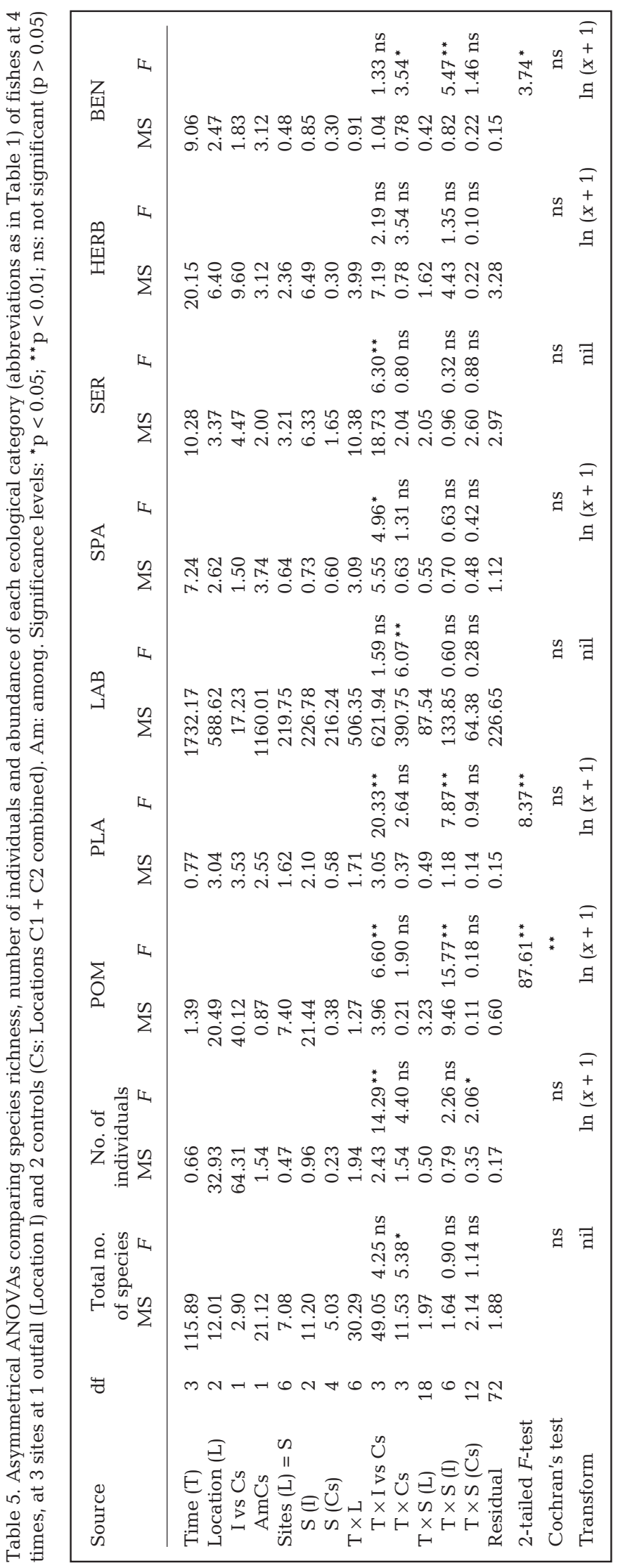

in the literature, but it seems fairly clear that sewage has the potential to alter fish communities worldwide (Russo 1989, Smith et al. 1999, Guidetti et al. 2002).

During this study, temporal trends in species richness were not affected by sewage pollution although, at the same outfall, Guidetti et al. (2002) found that spatial patterns in the number of fish species could be affected. In a study to assess the sewage impact on fish in Hawaii, Grigg (1994) concluded that species richness was a weak indicator of the effects of sewage pollution and that changes in relative fish abundance were more important in defining the effects of impact. In contrast, Smith et al. (1999) observed significant effects of an outfall on the decline (about 33\%) of species richness. Differences in the volume rate of effluent flow, the type of treatment, the types of pollutants discharged, concentrations of dissolved and particulate organic matter could all explain these apparently contradictory results. Hence, comparatively small, efficient, well-operated outfalls only causing moderate pollution may not negatively affect species richness. When, however, the discharged materials or the concentration of chemical pollutants, toxicants, etc. exceed a certain threshold, species richness may begin to decrease due to the progressive disappearance of pollution-sensitive species. Large, poorly treated or inefficiently operated outfalls may therefore have a more detrimental impact than well-designed treatment plants.

Fish abundance appears to be a useful variable for detecting the influence of sewage pollution. Marked increases in fish numbers (up to 7 -fold higher than in control areas) have been observed near sewage discharges by several authors (Russo 1982, Grigg 1994, Hall et al. 1997, Guidetti et al. 2002). This chiefly reflects the numerical increase in some dominant pollution-tolerant, ecological categories, i.e. PLA and POM feeders (Bell \& Harmelin-Vivien 1982, Grigg 1994, Hall et al. 1997). Such changes in the fish fauna may be ascribable to added nutrients and particulate organic matter introduced into the seawater column by sewage effluents (Scanes \& Philip 1995, but see also Chabanet et al. 1995 and references therein). Accordingly, POM feeders could directly benefit from the POM input as a food supplement, similarly to the situation in Hawaii (Russo 1989). During our field observations, mugilids were often seen foraging on POM in the effluent around the outfall. Nutrient enrichment at moderate levels, and the subsequent increase in food resources, could indirectly influence fish assemblages through a 'bottom-up' food chain mechanism (see Menge 

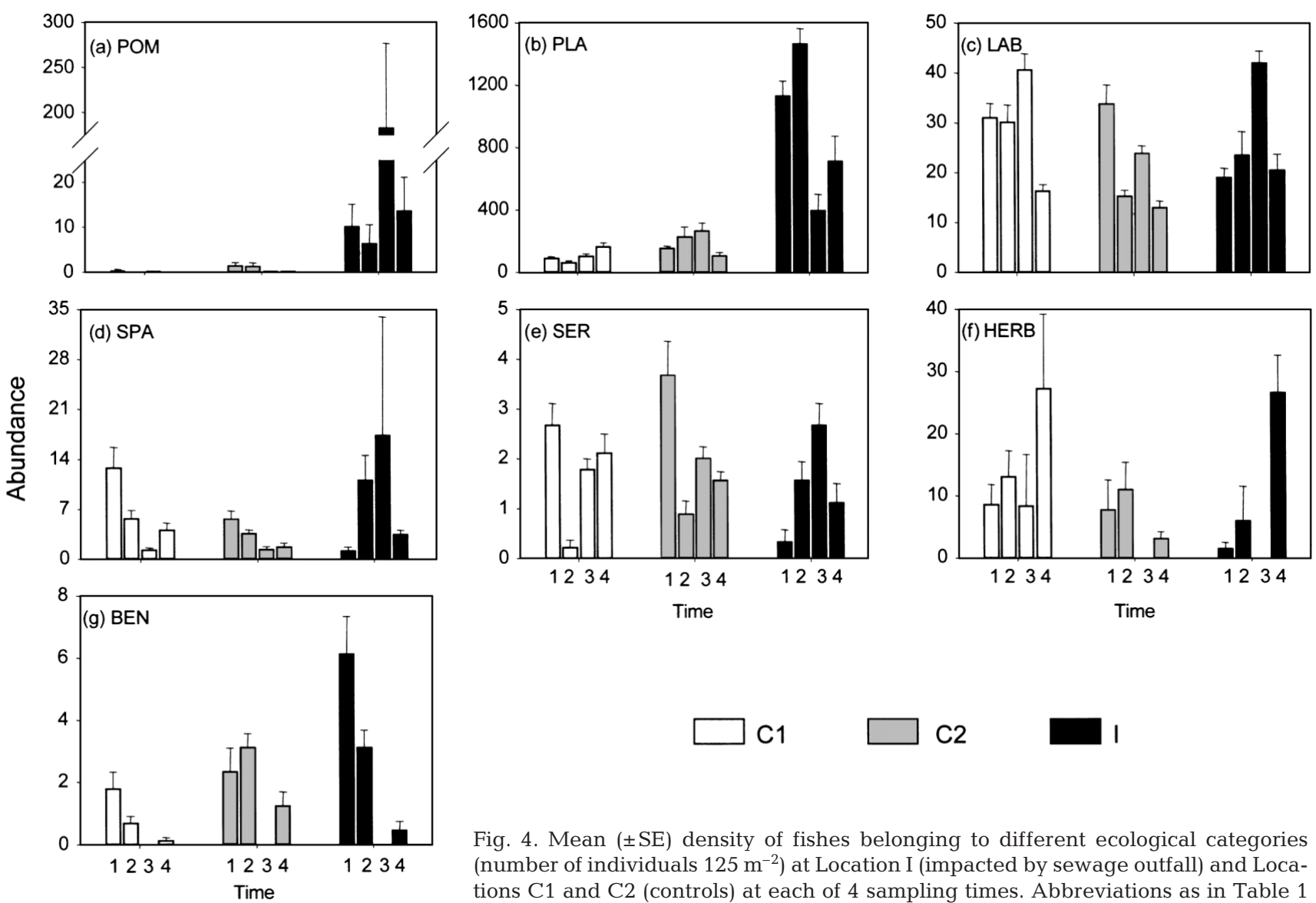

Fig. 4. Mean $( \pm \mathrm{SE})$ density of fishes belonging to different ecological categories (number of individuals $125 \mathrm{~m}^{-2}$ ) at Location I (impacted by sewage outfall) and Locations $\mathrm{C} 1$ and $\mathrm{C} 2$ (controls) at each of 4 sampling times. Abbreviations as in Table 1

2000 for review) by increasing the carrying capacity of marine systems. The increased availability of nutrients in the water column might enhance food webs from the phytoplankton upwards, including zooplankton, which constitute the main food source for small planktivorous fishes. In the Tyne Estuary (England), Hall et al. (1997) reported that total fish abundance rose by $300 \%$ at an outfall station, and that this variation was entirely due to an increase in small gregarious species. An increased density of planktivorous fishes was also observed by Bell \& Harmelin-Vivien (1982), who studied the influence of a sewage outfall on the fish fauna associated with the seagrass Posidonia oceanica near Marseille (France). Other authors also observed large numbers of juvenile fishes in and around sewage plumes (Gray 1996, Kingsford \& Gray 1996). Sewage plumes at Sydney (Australia), for instance, caused juvenile fishes (e.g. Carangidae and Sparidae) to aggregate at the plume fronts, probably because of advection of particulates attracting fishes to the plume. It is anyway difficult to determine the long-term effects of sewage plumes on young fishes, as well as the influence of the increased supply of particulate organic food on adult fish stocks over large spatial scales.
Besides the effects on synthetic variables (e.g. species richness and total fish abundance), we observed that the various ecological categories of fishes responded in different ways and magnitude to sewage pollution. Particulate feeders and planktivorous fishes displayed the most marked responses to sewage pollution. The spatio-temporal patterns of sparids, small serranids and small benthic fishes at the outfall differed from those in fishes from the control areas. This probably reflects the different responsiveness of the different ecological categories (and of each separate species) to disturbance. Chabanet et al. (1995) observed that eutrophication caused by urban and tourism developments in Reunion Island (Indian Ocean), induced an increase in macroalgae density which, however, did not affect all herbivorous fish species in the same way. The abundance of some of the more tolerant species (e.g. Naso unicornis) increased, whereas that of other more sensitive fishes (e.g. Ctenochaetus striatus) declined. Localised increases or reductions in the abundance of different fish species as a result of sewage pollution have also been reported for Australian waters by Otway et al. (1996) and Smith et al. (1999). 
A further consideration is the spatial scale(s) over which the outfall affected the variables examined. The average abundances of POM feeders and PLA fishes, for example, were affected at both site and location levels. Moreover, temporal variability among the outfall sites differed from that among control sites. This chiefly reflects the fact that these categories of fishes respond markedly to sewage inputs by progressively increasing their average abundance parallel to increasing concentrations of food in the wastewaters. Thus, their density can change over a spatial scale of several hundreds of metres, with highest abundances at the site in front of the outfall discharge. The SPA and SER were affected by sewage at the location level, whereas BEN responded at the scale of sites only. These differences could be ascribable to the different swimming abilities of these fish groups. Sea bream (sparids), for example, can move easily among sites within the same location, and thus their even distribution among sites at Location I may not reflect environmental effects at the site of major impact (i.e. the site immediately fronting the outfall). Benthic fishes (e.g. gobids and blennids), on the other hand, are strictly site-attached and less mobile, and they may more reliably reflect differences attributable to different levels of sewage impact.

In conclusion, our results indicate that monitoring fish assemblages together with benthic fauna may prove a useful refinement to management programmes designed to moderate sewage impact on littoral systems (e.g. improving the efficiency of the treatment plant in specific periods). However, the outfall does have an impact within the MPA and appropriate remedial action should be taken, such as the displacement of the outfall outlet into deeper waters far from the shore, in accordance with the current legal guidelines.

Acknowledgements. The research was funded by Regione Puglia (Interreg II Greece-Italy project) and MURST (COFIN project). Many thanks are due to A. Russo (University of Hawaii, USA) and T. Glasby (University of Sydney, Australia) for criticism on the draft manuscript and useful suggestions; to C. Vaglio for his invaluable assistance during field operations; and to 2 anonymous referees for having improved the paper.

\section{LITERATURE CITED}

Archambault P, Banwell K, Underwood AJ (2001) Temporal variation in the structure of intertidal assemblages following the removal of sewage. Mar Ecol Prog Ser 222:51-62

Austen MC, Warwick RM, Rosado MC (1989) Meiobenthic and macrobenthic community structure along a putative pollution gradient in southern Portugal. Mar Pollut Bull 20:398-405

Bell JD, Harmelin-Vivien ML (1982) Fish fauna of French Mediterranean Posidonia oceanica seagrass meadow: community structure. Tethys 10:337-347
Chabanet P, Dufour V, Galzin R (1995) Disturbance impact on reef fish communities in Reunion Island (Indian Ocean). J Exp Mar Biol Ecol 188:29-48

Clarke KR (1993) Non-parametric multivariate analyses of changes in community structure. Aust J Ecol 18:117-143

Clarke KR, Warwick RM (1994) Change in marine communities: an approach to statistical analysis and interpretation. Natural Environment Research Council, Swindon

Costanzo SD, O'Donohue MJ, Dennison WC, Loneragan NR, Thomas M (2001) A new approach for detecting and mapping sewage impacts. Mar Pollut Bull 42:149-156

Danielson BJ (1991) Communities in a landscape: the influence of habitat heterogeneity on the interactions between species. Am Nat 138:1105-1120

Dayton P (1984) Processes structuring some marine communities: are they general? In: Strong D, Simberloff DS, Thistle $\mathrm{AB}$ (eds) Ecological communities: conceptual issues and the evidence. Princeton University Press, Princeton, NJ, p 181-197

Diener DR, Fuller SC, Lissner A, Haydock CI, Maurer D, Robertson G, Gerlinger T (1995) Spatial and temporal patterns of the infaunal community near a major ocean outfall in Southern California. Mar Pollut Bull 30:861-878

Estacio FJ, Garcìa-Adiego EM, Fa DA, Garcìa-Gomez JF, Daza JL, Hortas F, Gòmez-Ariza JL (1997) Ecological analysis in a polluted are of Algeciras Bay (southern Spain): external versus internal outfalls and environmental pollution. Mar Pollut Bull 34:780-793

Frontier S (1986) La méthode des cotations d'abondance appliquée aux pêcheries artisanales. In: Frontier S (ed) Evaluation et optimisation des plans d'échantillonnage en écologie littorale. Piren, ATP 9-82-65. Centre National de la Recherche Scientifique, Paris, p 262-285

Glasby TM (1997) Analysing data from post-impact studies using asymmetrical analyses of variance: a case study of epibiota on marinas. Aust J Ecol 22:448-459

Gray CA (1996) Intrusions of surface sewage plumes into continental shelf waters: interactions with larval and presettlement juvenile fishes. Mar Ecol Prog Ser 139:31-45

Grigg RW (1994) Effects of sewage discharge, fishing pressure and habitat complexity on coral ecosystems and reef fishes in Hawaii. Mar Ecol Prog Ser 103:25-34

Guidetti P, Fanelli G, Fraschetti S, Terlizzi A, Boero F (2002) Coastal fish indicate human-induced changes in the Mediterranean littoral. Mar Environ Res 53:77-94

Hall JA, Frid CLJ, Gill ME (1997) The response of estuarine fish and benthos to an increasing discharge of sewage effluent. Mar Pollut Bull 34:537-535

Harmelin-Vivien ML, Francour P (1992) Trawling or visual censuses? Methodological bias in the assessment of fish populations in seagrass beds. PSZN I:Mar Ecol 13:41-51

Harmelin-Vivien ML, Harmelin JG, Chauvet C, Duval C and 7 others (1985) Evaluation des peuplements et populations de poissons: méthodes et problèmes. Rev Ecol Terre Vie 40:467-539

Kingsford MJ, Gray CA (1996) Influence of pollutants and oceanography on abundance and deformity of wild fish larvae. In: Schmitt RJ, Osenberg CW (eds) Detecting ecological impacts. Academic Press, London, p 235-255

Menge BA (2000) Top-down and bottom-up community regulation in marine rocky intertidal habitats. J Exp Mar Biol Ecol 250:257-289

Otway NM, Sullings DJ, Lenehan HW (1996) Trophicallybased assessment of the impacts of deepwater sewage disposal on a demersal fish community. Environ Biol Fish 46: 167-183

Pearson TH, Rosenberg R (1978) Macrobenthic succession in 
relation to organic enrichment and pollution of the marine environment. Oceanogr Mar Biol Annu Rev 16:229-311

Pomfret JR, Elliot M, O'Reilly MG, Phillips S (1991) Spatial and temporal patterns in the fish communities in two U.K. North Sea estuaries. In: Elliot M, Ducrotoy JP (eds) Estuaries and coasts: spatial and temporal intercomparisons. Olsen \& Olsen, Fredensborg, p 227-284

Raimondi PT, Reed DC (1996) Determining the spatial extent of ecological impacts caused by local anthropogenic disturbances in coastal marine habitats. In: Schmitt RJ, Osenberg CW (eds) Detecting ecological impacts. Academic Press, London, p 179-198

Roberts DE, Smith A, Ajani P, Davis AR (1998) Rapid changes in encrusting marine assemblages exposed to anthropogenic point-source pollution: a 'beyond BACI' approach. Mar Ecol Prog Ser 163:213-224

Russo AR (1982) Temporal changes in fish community structure near a sewage ocean outfall, Mokapu, Oahu, Hawaii. Mar Environ Res 6:83-98

Russo AR (1989) Fish community structure on a deep ocean outfall, Barber's Point, Oahu, Hawaii. Int Rev Ges Hydrobiol 74:499-506

Scanes PR, Philip N (1995) Environmental impact of deepwater discharge of sewage off Sydney, NSW, Australia. Mar Pollut Bull 31:343-346

Schmitt RJ, Osenberg CW (eds) (1996) Detecting ecological impacts. Academic Press, London

Shepherd AR, Warwick RM, Clarke KR, Brown BE (1992) An analysis of fish community response to coral mining in the Maldives. Environ Biol Fish 33:367-380

Smith AK, Ajani PA, Roberts DE (1999) Spatial and temporal variation in fish assemblages exposed to sewage and implications for management. Mar Environ Res 47:241-260

Smith SDA (1996) The effects of domestic sewage effluent on marine communities at Coffs Harbour, New South Wales, Australia. Mar Pollut Bull 33:7-12

Soltan D, Verlaque M, Boudouresque CF, Francour P (2001)

Editorial responsibility: Tony Underwood (Contributing Editor), Sydney, New South Wales, Australia
Changes in macroalgal communities in the vicinity of a Mediterranean sewage outfall after setting up of a treatment plant. Mar Pollut Bull 42:59-70

Terlizzi A, Fraschetti S, Guidetti P, Boero F (2002) The effects of sewage discharge on shallow hard substrate sessile assemblages. Mar Pollut Bull 44:544-550

Underwood AJ (1991) Beyond BACI: experimental designs for detecting human environmental impacts on temporal variations in natural populations. Aust J Mar Freshw Res 42: 569-587

Underwood AJ (1992) Beyond BACI: the detection of environmental impacts on populations in the real, but variable, world. J Exp Mar Biol Ecol 161:145-178

Underwood AJ (1993) The mechanisms of spatially replicated sampling programmes to detect environmental impacts in a variable world. Aust J Ecol 18:99-116

Underwood AJ (1994) On beyond BACI: sampling designs that might reliably detect environmental disturbances. Ecol Appl 4:3-15

Underwood AJ (1997) Experiments in ecology: their logic design and interpretation using analysis of variance. Cambridge University Press, Cambridge

Underwood AJ (2000) Importance of experimental design in detecting and measuring stress in marine populations. J Aquat Ecosyst Stress Recov 7:3-24

Underwood AJ, Chapman MG (1996) Subtidal assemblages on rocky reefs at a cliff-face sewage outfall (North Head, Sydney, Australia): what happened when the outfall was turned off? Mar Pollut Bull 33:293-302

UNEP (United Nations Environment Programme) (1989) State of the Mediterranean marine environment. MAP Tech Rep Ser 28

Warwick RM (1993) Environmental impact on marine communities: pragmatical considerations. Aust J Ecol 18:63-80

Warwick RM, Clarke KR (1993) Increased variability as a symptom of stress in marine communities. J Exp Mar Biol Ecol 172:215-226

Submitted: April 16, 2002; Accepted: January 8, 2003

Proofs received from author(s): April 22, 2003 